\section{China signs up for participation in EU's Framework}

[MUNICH] The European Commission has signed a cooperation agreement on science and technology with the Republic of China that will allow Chinese scientists to participate in its fifth Framework programme of research, which was approved by the European Council of Ministers late last month.

The agreement gives European scientists the reciprocal right to participate in Chinese research programmes. The agreement involves no exchange of money - scientists on both sides will have to pay their own way but will have access to common results.

This is the first time the commission has signed such an agreement with a developing economy, but it will not be the last. Negotiations are continuing with Argentina and India, and informal discussions are taking place with other countries.

The European Molecular Biology Organization (EMBO) last year set up the European Biotechnology Node for Interactions with China (http://www.ebnic.org) to help build contacts between European and Chinese scientists, and promote their participation in the Framework programme.

Frank Gannon, executive director of EMBO, explains: "The challenge to European scientists to find their way to the fifth Framework programme is enormous. The challenge to our colleagues in China is nearly unimaginable."

Alison Abbot

\title{
Brazil brings in reforms of science funding agency
}

[SÃO PAULO] Brazil's science funding agency is being shaken up as part of broad government changes introduced to coincide with the second term of the country's president, Fernando Henrique Cardoso.

The new minister of science, Luiz Carlos Bresser Pereira, will temporarily head the National Council for Scientific and Technological Development (CNPq). And the administration of the council is being brought closer in line with similar funding agencies abroad.

Cardoso had considered merging the Ministry of Science and Technology with the larger Ministry of Education (see Nature 396,$503 ; 1998$ ). But he decided to keep them separate, and make the changes inside each.

Bresser Pereira replaced José Israel Vargas, who had headed the science ministry since the government of Cardoso's predecessor, Itamar Franco. José G. Tundisi, a former president of $\mathrm{CNPq}$, is to head the committee responsible for the council's reorganization.

Fernando Reinach, a molecular biologist at the University of São Paulo and a campaigner for reforms, who had been asked to review the new structure of the $\mathrm{CNPq}$, has been appointed by Bresser Pereira as his secretary for science policy (see Nature 392, 647-648; 1998).

The independence from political interference of the $\mathrm{CNPq}$, which was created in the late 1940s, has always been prized by Brazilian scientists. But when the science ministry was created in 1985 , it took on responsibility for the agency, creating a source of friction.

The ministry, for example, had three top officials - one for scientific development, one for technological development, and a third for information technology - each of whom was involved in science policy decisions.

Under the new reforms, these will be replaced by three new $\mathrm{CNPq}$ vice-presidencies, each working as a separate funding council: one for biomedical research, another for humanities, and another for physical sciences and engineering. According to Reinach, each of these posts will legally have to be filled by a working scientist.

CNPq's previous responsibility for a number of scientific institutes will be taken over by the ministry. "Basically, we are increasing the participation of scientists in the ministry," says Reinach.

Several scientists will serve on the committee that will draw up the details of the reform, including Moacyr Krieger, president of the Brazilian Academy of Sciences. Others who have discussed the reform with the minister include biologist Sérgio Ferreira, president of the Brazilian Society for the Development of Science.

\section{Energy department revises terms of Venter deal after complaints}

[WASHINGTON] Leaders of the publicly funded Human Genome Project have rejected a proposed memorandum of understanding between one of the project's participants, the US Department of Energy (DoE), and Celera, the corporation established by geneticist Craig Venter in a rival bid to sequence the genome.

There had been concern that clauses in the proposed agreement would have been in conflict with the desire for open access to sequence data. But the leaders of the government project still hope that the DoE can reach an agreement with Celera before the corporation starts its sequencing work this spring (see Nature 393, 101; 1998).

The National Human Genome Research Institute (NHGRI) at the US National Institutes of Health (NIH) and the UK Wellcome Trust - the two largest participants in the international genome project - last month scotched the draft agreement under which Celera and the DoE would have exchanged sequence information on the three chromosomes of the genome that are being sequenced by the DoE.

Francis Collins, director of the NHGRI, says his institute and the trust were "uncomfortable" with the draft because it would have required DoE scientists to work with data from Celera that was not publicly available, and it involved the government agency in providing a service to a single, profit-making corporation. The draft would have been "in violation of the international consensus to have sequence data released immediately" into the public domain.

Collins and Michael Morgan, a senior official responsible for the genome project at the Wellcome Trust, asked Ari Patrinos, head of biological and environmental research at DoE, to come up with a new agreement.

Patrinos now concedes that the draft would have "given some scientists an early peek" at genome data, and that this was "inappropriate and incorrect". Patrinos expects that a new agreement will be negotiated.
Committees of the US Congress have pressed the NIH and DoE to collaborate with Venter's effort, but differing approaches to the release of data will make this easier said than done. The government project requires all sequence material to be published immediately. Celera wants to keep its data secret for three months - scouring it for information that can be patented before sharing it with the outside world.

Collins says he is unsure how the agreement can be made to work, but says that "no data will be exchanged that is not publicly available".

Paul Gilman, head of policy at Celera, says the corporation will be receptive to any new proposal from the public agencies, but that it "hadn't heard a word from them" since the draft was withdrawn in December.

Collins strongly denied a report in Time magazine that "sour grapes" at the NIH was behind the rejection of the draft. Venter has a history of friction with the NIH, which he left in 1992 after an explosive public argument over gene patents. Colin Macilwain 